ljtihad: Jurnal Wacana Hukum Islam dan Kemanusiaan

Vol. 19, No. 1 (2019), pp. 125-145, doi : 10.18326/ijtihad.v19i1.125-145

\title{
Pendekatan kriminologi dan gender terhadap model kurikulum pembinaan narapidana anak kelas I Blitar
}

\author{
Saifullah, Abdul Bashith, Mufidah Ch \\ Universitas Islam Negeri Maulana Malik Ibrabim Malang \\ E-mail: saifullahdebab@yahoo.co.id,abbash98@pips.uin-malang.ac.id, \\ Fidah_cholil@yahoo.co.id \\ DOI: 10.18326/ijtihad.v19i1.125-145
}

This study is aimed to elaborate the criminology and gender approaches taken to provide curriculum material contents in forming curriculum models for fostering child detainees in the child prison. Using legal and conceptual approaches, this study elaborates the findings as follows: in the criminology perspective, to provide curriculum material contents in forming curriculum models for fostering child detainees in child prison is by using religious approach, completing facilities and infrastructures, optimizing employee roles, applying formal education in prison, giving treatment and health care, supporting for the creation of social recovery, giving remission of crimes and assimilated opportunities including a leave to visit family or parole and a leave before being released. Whereas, in the gender perspective, it is by not distinguishing between sexes during the treatment to them. In addition, the final result of the curriculum model formation for fostering child detainees in child prison of LPKA (Child-specific Guidance Institution) in Blitar can be referred to as; the treatment system for correctional students in prison. This system consists of input in the form of an initial stage of 0 to $1 / 3$ course with an administrative orientation pattern; the advanced stage consists of $1 / 3$ to $1 / 2$ course and $1 / 2$ to $2 / 3$ course; the final stage is $2 / 3$ to any uncertain course stage with the achievement of correctional goal that is social reintegration: live, life, livelihood.

Riset ini bertujuan untuk menjelaskan pendekatan kriminologi dan gender yang dilakukan dalam memberikan muatan materi kurikulum terhadap pembentukan model kurikulum pembinaan narapidana anak di lembaga pemasyarakatan anak dan membuat model kurikulum pembinaan narapidana anak di lembaga pemasyarakatan anak. Dengan menggunakan pendekatan perundangundangan dan konseptual, riset ini menjelaskan temuan sebagai berikut: Dalam perspektif kriminologi, dalam memberikan muatan materi kurikulum terhadap pembentukan model kurikulum pembinaan narapidana anak di lembaga pemasyarakatan anak adalah pendekatan Agama, Pelengkapan 
Sarana dan prasarana, Optimalisasi peranan Pegawai, Penerapan Pendidikan formal dalam Lapas, Pemeliharaan dan Perawatan Kesehatan, Daya dukung terciptanya Pemulihan Sosial, Pengurangan Masa Pidana (remisi), Kesempatan berasimilasi termasuk cuti menunjungi keluarga dan pembebasan bermasyarkat serta cuti menjelang bebas. Sedangkan dalam perspektif gender, ditemukan bahwa dalam perlakuan terdapat anak bermaslah adalah dengan tidak membedakan jenis kelamin. Selain itu, hasil akhir pembentukan model kurikulum pembinaan narapidana anak di lembaga pemasyarakatan anak LPKA (Lembaga Pembinaan Khusus Anak) Blitar dapat disebut sebagai: Sistem Perlakuan Anak Didik Pemasyarakatan. Sistem ini terdiri atas Input berupa tahap awal $0 \mathrm{~s} / \mathrm{d} 1 / 3 \mathrm{MP}$ dengan pola admini orientasi; tahap lanjutan terdiri $1 / 3$ sd $1 / 2$ MP dan $1 / 2$ sd $2 / 3$ MP; tahap akhir $2 / 3$ MP-Bebas yang diakhir dengan tercapainya tujuan pemasyarakatan yaitu reintegrasi sosial: hidup, kehidupan dan penghidupan.

Keywords: Curriculum Model, Child Prisoner, Criminology, Gender

\section{Pendahuluan}

Setiap perjalanan pembangunan baik yang bersifat fisik maupun phisikis selalu embawa dampat negatif atau ekses terhadap pembangunan itu sendiri. Arus globalisasi yang berjalan seiring dengan pembangunan memberikan efek yang sangat luas pada seluruh stratifikasi dalam masyarakat. Kondisi ini menjadi hal yang paling memprihatikan jika melihat anakanak bangsa yang disebut sebagi sampah masyarakat. Mereka yang terkategorikan ini bukan saja produk dari zamannya tetapi jauh lebih luas bahwa peradaban suatu bangsa tidak bisa dilepaskan dari tanggungjawab untuk menggiring seluruh kemajuan anak bangsa pada semua lini masyarakat.

Ekses-ekses itu bisa jadi muncul karena merupakan bagian yang tidak terpecahkan dari persoalan mendasar manusia yang dari berbagai sisi sudah dilakuklan survei. Salah satu contoh ekses dari kemajuan bangsa adalah kriminalitas. Kriminalitas yang kita lihat saat ini tidak saja Kriminalitas yang dilakukan oleh orang dewasa tetapi juga oleh anakanak pria maupun wanita yang rentang usia mereka sekitar 12 sampai di bawah 18 tahun menurut UU Perlindungan Anak. Kekhasan perilaku kejahatan oleh anak menjadikan keprihatinan yang mencul sebagai bagian yang urgent dari menyiapkan generasi bangsa di masa depan.Jika Masalah kriminalitas ini tertangani dengan baik maka kita sesungguhnya tel;ah menyelamatkan peradaban suatu bangsa misalnya dengan upaya preventif dengan mencegah atau meminimalisir kejahatan anak. 
Sumbangsih seluruh lini atau sektor yang bergerak dalam pemberdayaan anak dan perempuan seringkali dikatakan menjadi kata kunci untuk mengukur suatu keberhasilan apakah program yang mengentaskan anak dari kasus hukum bisa berhasil ataukah tidak. Selama ini pandangan-pandangan semacam ini seringkali menjadi persoalan untuk melimpahkan siapa sesungguhnya yang bertanggungjawab penuh atas anak yang berhadapan dengan hukum, yang serta merta menjadi pertanyaan kita semua. Banyak hasil riset menyebutkan bahwa semua lini atau sektor bertanggungjawab penuh atas positif dan negatif dari perilaku kejahatan yang dilakukan oleh anak. Mata rantai ini sebagai gambaran dari perlunya kita melakukan penelaahan yang mendalam agar kelak dapat "dimasyakatkan kembali" dan pulih sebagaimana sediakala.

Perilaku anak yang menyimpang dari norma-norma dalam harmonisasi kehidupan baik yang tidak tertulis maupun yang tertulis seperti peraturan perundang-undangan akan memberikan sanksi pada siapa saja yang melakukan tindak pidana. Kejahatan yang dilakukan anak ini adalah bukti riil dari kenyataan yang terjadi di masyarakat yang sesungguhnya anak itu sendiri tidak menghendakinya. Kita memahami bahwa anak yang dilahirkan dari setiap zaman mempunyai perbedaan perlakuan dengan zaman di masa lalu. Konteks ini sesungguhnya untuk memperlihatkan pada kita semua bahwa kejahatan yang dilakukan anak berbanding lurus dengan persoalan-persoalan sosial yang ada di dalam masyarakat. Persoalan-persoalan tersebut di antaranya pengaruh globalisasi yang berdampak pada kemajuan informasi dan teknologi, adanya urbanisasi yang memunculkan kepadatan penduduk di kota-kota metropolitan yang memunculkan nilai-nilai individualis yang memicu nilai-nilai kecemburuan sosial yang tinggi yang berdampak pada tingginya kejahatan baik dari sisi kualitas modus operandinya maupun dari sisi kuantitas secara statistik. Anak ada dalam pusaran problematika kejahatan tersebut.

Masuknya anak di bawah umur dalam pusaran kejahatan adalah hal yang tidak bisa dipungkiri. Walaupun secara statistik jumlah pelaku kejahatan anak di bawah dari pelaku dewasa, tapi perlu dicermati bahwa mereka adalah bibit baru atau calon penjahat masa depan jika tidak ditangani dengan baik. Sudah banyak riset yang merekomendasikan bagaimana faktor-faktor yang mempengaruhi kejahatan anak bisa terjadi di antaranya faktor kemiskinan, lingkungan, salah didik, keluarga tidak harmonis dan pendidikan agama 
yang sangat kurang berpotensi besar munculnya kasus-kasus anak yang berhadapan dengan hukum. Namun jika ditelusuri, karena secara psikis maupun fisik anak masih dalam proses pertumbuhkembangan dalam berbagai aspek maka sesungguhnya kejahatan dari luar itulah yang secara eksternal mempengaruhi pola pikir dan jiwa anak, bukan aspek dari dalam dirinya yang masih labil dan secara akal sehat belum bisa membedakan mana norma yang baik dan tidak baik. Faktor pemicu di atas bukan menjadi sebatas alat pembenar untuk mengklaim bahwa hal tersebut menjadi penyebab utama.

Pelaku dengan status anak menjadi perhatian pemerintah terutama pelaku anak di bawah umur. Posisi anak yang melakukan kejahatan yang diistilahkan dengan anak berhadapan dengan hukum bukan hanya persoalan biasa tetapi sudah masuk kategori extra ordinary crime selain kejahatan teroris, kejahatan narkotika dan kejahatan korupsi yang menjadi prioritas pemerintah untuk menyelesaikannya. Data dari KPAI memaparkan kasus pengaduan anak berdasarkan bidang pengaduan hingga Bulan Juli 2015 di bawah ini menunjukkan selama 6 tahun terakhir yang paling banyak pengaduan adalah anak berhadapan dengan hukum sejumlah 6.147 kasus di bandingkan dengan kasus-kasus lain.

Pemerintah memandang sangat serius kejahatan yang dilakukan oleh anak. Oleh sebab itu pola pembinaan yang dilakukan oleh pemerintah selain program preventif juga kuratif. Pola kuratif dilakukan dengan pola pembinaan di Lembaga Pemasyarakatan Anak (LP Anak). Sebagai sebuah lembaga pemasyarakatan yang serius mengadakan program pembinaan pada napi anak, keberadaan LP Anak menjadi kunci keberhasilan bagi penanggulangan kejahatan baik itu untuk program kuratif maupun preventif.

\section{Metode Penelitian}

Penelitian yang penulis lakukan adalah mengacu pada perpaduan dua penelitian dalam metodologi penelitian hukum yaitu penelitian yuridis normatif (penelitian hukum doktriner) dan penelitian yuridis sosiologis (penelitian hukum non doktriner). Perpaduan kedua pendekatan ini memungkinkan hasil analisis dan rekomendasi dapat berjalan maksimal (Soedjono, dkk, 1999: 56; Brannen, 1997: 20; Moleong, 1995: 22; Strauss \& Corbin, 1990: 12; Patton, 1989: 115; Bisri, 2004: 277). Penelitian ini menggunakan pendekatan perundangundangan (statute approach) dan pendekatan konseptual (conceptual approach). Pendekatan 
perundang-undangan (statute approach) yaitu penelitian terhadap produk-produk hukum (Marzuki, T.th: 138.). Produk hukum yang dimaksud adalah produk hukum yang berkenaan dengan perlindungan hukum dan pembinaan anak di lembaga pemasyarakatan anak. Pasal 28 H UUD NRI 1945, UU No. 23 Tahun 2002 Tentang Perlindungan Anak, UU No. 35 Tahun 2014 Tentang Perubahan UU No. 23 Tahun 2002 Tentang Perlindungan Anak, UU No. 39 Tahun 1999 Tentang Hak Asasi Manusia, dan Keputusan Presiden Republik Indonesia Nomor 36 Tahun 1990 tentang Rativikasi Convention On The Right of The Child (Konvensi Hak-Hak Anak).

Pendekatan konseptual (conceptual approach) beranjak dari pandangan-pandangan dan doktrin-doktrin yang berkembang di dalam ilmu hukum, untuk menemukan ide-ide yang melahirkan konsep-konsep hukum, dan asas-asas hukum yang relevan dengan isu hukum (Marzuki, t.th: 95). Metode pengumpulan data ada tiga yaitu, (1) studi lapangan dilakukan dengan peninjauan pada lokasi penelitian. Survey pada lokasi penelitian tersebut bertujuan mendapatkan data primer yang dilakukan dengan metode wawancara bebas terpimpin berpedoman pada kuesioner terbuka yang disusun; proses wawancara berlangsung dinamis sehingga bersifat kondisional. Wawancara model ini akan menghasilkan jenis pertanyaan yang lebih bervariasi dan tidak tergantung pada pedoman wawancara yang telah disiapkan. Adapun yang menjadi informan adalah para pengambil kebijakan, mulai dari Kanwil Kemhumham sampai pada kepala Lapas Anak dan para napi anak di Blitar. (2) Studi dokumentasi tidak saja bertujuan mengumpulkan dokumen tetapi juga menelaah secara mendalam dokumen yang terkait pada pembinaan napi yakni beberapa peraturan perundang-undangan yang terkait termasuk di dalamnya kajian kepustakaan yang relevan dan keseluruhan data yang terkumpulkan adalah data sekunder. (3) Sampel dan Teknik Sampling Populasi penelitian ini adalah keseluruhan LP Anak se-Indonesia. Sedangkan yang dijadikan sampel adalah LP Anak Blitar yang merupakan satu-satunya LP Anak di Jawa Timur. Bentuk penentuan sampel dalam penelitian semacam ini disebut dengan purposive sampling.

Selama proses pengumpulan data primer dan data sekunder tersebut diupayakan pula penjagaan serta pemeriksaan keabsahan data. Terdapat empat tipe standar yang dilakukan untuk menjamin kesahihan (validitas) dan keandalan (reliabilitas) hasil penelitian, seperti 
yang dikemukakan oleh Yvonna S. Lincoln dan Egon G. Guba, yaitu standar kredibilitas, standar transferabilitas, standar dependabilitas dan standar konfirmabilitas (Moleong, 1995: 170-188; Muhadjir, 1992: 157-159; Faisal, 1990: 31-34; S.Nasution, 1996: 114-122). Metode pengolahan data dilakukan melalui beberapa fase (1) Meneliti kembali data-data yang didapat untuk kemudian diteliti lagi mengenai validitas atau kajian literature serta kejelasan data yang diperoleh merupakan prioritas pekerjaan yang dilakukan. Tujuan dilakukannya penelitian data ini agar data primer dan data sekunder yang diperoleh dapat maksimal dan terjamin otentisitasnya. (2) Melakukan pencatatan secara sistematis dan konsisten bahwa data yang diperoleh dituangkan dalam rancangan konsep untuk kemudian dijadikan bahan utama bagi proses analisis sehingga pada akhirnya akan didapatkan keseimbangan data dengan bentuk analisis yang akan dilakukan. Teknik pengolahan data secara kuantitatif maupun kualitatif yang dilakukan di atas bersifat saling mendukung, sehingga diupayakan proses pendeskripsian sesuai dengan nilai objektifitas penelitian ilmiah yang dinginkan dan mendekati realitas sosial yang terjadi.

Metode analisis dan penyajian data dengan metode penelitian di atas dimaksudkan untuk mendapatkan data pendukung rumusan masalah baik berupa data primer maupun data sekunder. Adapun masalah yang diajukan dianalisis sesuai dengan ruang lingkup permasalahan dan dikaji berdasarkan landasan konseptual. Untuk permasalahan yang pertama dilakukan kajian content analysis yakni analisis isi atau kajian isi (Nawawi, 1983: 68; Moleong, 1995: 179; Sumadi 1991: 94; Miles dan Huberman, 1984; Brannen, 1997). Selanjutnya untuk permasalahan yang kedua dilakukan analisis deskriptif-kualitatif yaitu data yang bersifat kualitatif yang digambarkan dengan kata-kata atau kalimat dipisahpisahkan menurut kategori untuk memperoleh kesimpulan. Selanjutnya dilakukan editing untuk membetulkan data yang keliru, menambahkan data yang kurang, melengkapi data yang belum lengkap (Soemitro, 1990: 80). Secara lebih terperinci pola analisis deskriptif kualitatif dimulai dengan mereduksi data, pemerosesan satuan, kategorisasi termasuk pemeriksaan keabsahan data, diakhiri dengan penafsiran data dalam mengolah hasil sementara menjadi teori substantif. 
Pendekatan kriminologi dan gender terhadap model kurikulum... (Saifullah, dkk.)

\section{Deskripsi umum lembaga pemasyarakatan anak}

Tipologi Anak LAPAS Anak Kelas I Blitar adalah anak yang berdasarkan keputusan pengadilan telah melanggar hukum dan aturan Negara. Anak ini dimasukkan ke LAPAS dengan berbagai aturan baru yang harus ditaati. Beberapa anak mengaku memiliki kesusahan untuk menyesuaikan keadaan LAPAS yang sangat berbeda dari kehidupan sebelumnya meskipun berbagai kegiatan telah diberikan, anak-anak tetap mengaku merasa bosan dengan kegiatan yang sudah ada.

Kegiatan yang sering dilakukan oleh anak selama di LAPAS adalah kegiatan pendidikan, keterampilan kerja, seni, keagamaan dan olahraga. Ketika pertama kali masuk di LAPAS, anak-anak akan ditanya soal memilih kegiatan yang ingin diikutinya. Anak hanya dapat mengikuti satu hingga dua kegiatan setiap harinya. Selain mengikuti kegiatan tersebut, beberapa anak menggunakan waktunya untuk bergurau, bercerita dan menonton TV. Beberapa anak juga tampak berkumpul di beberapa titik sudut LAPAS.

Penghuni Wisma Dahlia memang memiliki perbedaan dari penghuni wisma lainnya. Selain karena usia, penghuni Wisma Dahlia lebih tampak pasif untuk mengikuti kegiatan yang ada di LAPAS. Anak-anak lebih banyak menghabiskan waktu di kamar daripada berkumpul atau mengikuti keterampilan di LAPAS. Selain itu, penghuni Wisma Dahlia juga memiliki kelompok-kelompok kecil dalam menjalin pertemanan. Kelompok ini biasanya terjadi karena bahasa yang sering digunakan, seringnya kunjungan dari keluarga, dan kecocokan secara personal.

Beberapa anak juga menyebutkan bahwa tidak semua orang bisa berbagi dalam semua hal. Setiap barang menjadi tanggung jawab pribadi. Anak-anak juga tidak semuanya dapat peduli dan akrab dengan yang lainnya. Beberapa anak dengan kualifikasi yang berbeda dari kelompok mendapat perlakuan yang berbeda. Jika anak tidak dapat menerima dan mengontrol dirinya, perkelahian biasanya akan terjadi. Meskipun disadari bahwa perkelahian bukan penyelesaian terakhir dari masalah tersebut karena masuk sel adalah hukuman yang akan didapat oleh anak saat melanggar aturan.

Kedisiplinan dan ketaatan memang diajarkan dan ditanamkan pada warga binaan. Setiap anak diajarkan untuk mengikuti semua aturan yang ada di LAPAS. Beberapa anak memang terlihat mengikuti semua aturan di LAPAS. Anak-anak tersebut mengaku patuh 
karena telah pernah mendapatkan hukuman sel dari pihak Kepala Pengamanan Lembaga Permasyarakatan (KPLP). Akan tetapi, beberapa anak lain masih sering melanggar aturan LAPAS, seperti melakukan hutang-piutang, membawa HP, membuat tato, membuat kelompok mayoritas dan minoritas, serta menggunakan obat-obatan psikotropika. Selain masalah ketertiban dan kedisiplinan, anak-anak dengan latar belakang yang berbeda juga membuat timbulnya permasalahan pertemanan di antara warga binaan. Keluarga, keadaan ekonomi, pendidikan, dan pola pikir yang menjadi sebab satu anak berbeda dengan lainnya. Kelompok-kelompok yang terbentuk karena hal tersebut membuat beberapa anak tidak dapat menyesuaikan diri dalam kelompok tertentu. Kelompok tertentu juga membatasi diri dari orang lain.

Pada dasarnya, anak-anak tidak diperbolehkan untuk membuat kelompok. Anak-anak juga mengaku saling akrab dan peduli dengan yang lainnya. Akan tetapi jika waktu luang, kelompok tersebut tampak. Oleh sebab itu, permasalahan yang tampak dari penghuni wisma dahlia adalah rendah minat mengikuti kegiatan, adanya kelompok kecil yang terbentuk secara tidak sengaja, dan beberapa perkelahian kecil hingga berat pun sering terjadi.

Permasalahan-permasalahan yang ada pada LAPAS ini sebenarnya tidak jauh berbeda dengan permasalahan yang ada di luar. Warga binaan dengan berstatuskan remaja sering memiliki permasalahan pertemanan dan emosi, misalnya, $\mathrm{MH}$. $\mathrm{MH}$ adalah narapidana kasus perampokan yang berusia 16 tahun. Awalnya anak ini adalah penghuni wisma dahlia. Akan tetapi, karena permasalahan dengan teman sekamarnya. MH di pmdah ke Wisma Bugenfil. Anak ini dipercaya untuk betanggung jawab membersihkan masjid. Beberapa kali anak ini terlihat lebih sering duduk di bawah pohon daripada berkumpul bersama temantemannya. Anak ini sering terlihatdiam dan menyendiri dibandingkan penghuni lainnya. Menurui beberapa teman di Wisma Dahlia, MH juga sering tertangkap mencuri barang milik temannya. Selain itu, masalah perkelahian telah terjadi sebanyak dua kali selama anak ini tinggal di LAPAS Anak Keias 11A Blitar. Beberapa anak penghuni Wisma Dahlia juga merasa kurang peduli dengan MH. Anak ini belatar belakang yatim piatu sehingga tidak ada lagi yang mengunjunginya selama di LAPAS. Kelompok kecil yang terbentuk membuat anak ini merasa dijauhi temannya. MH merasa bahwa temannya tidak suka dengannya karena tidak pernah dikunjungi. Akhimya anak ini lebih memilih untuk menyendiri daripada 
berkumpul bersama penghuni lainnya. Beberapa anak juga memiliki tatapan sinis terhadap MH ketika berjalan di depannya. Beberapa bulan kemudian MH terlibat lagi pertengkaran dengan teman sekamar. Masalah ini dilatarbelakangi oleh masuknya salah satu temannya ke dalam sel. MH dituduh melaporkan temannya ke petugas karena membawa handphone. Akhimya, MH melaporkan ke petugas bahwa beberapa teman telah memukulinya.

Bentuk perlindungan hukum narapidana anak di pemasyarakatan anak Blitar dalam perspektif kriminologi dan gender

Di dalam Lembaga Pemasyarakatan Anak Blitar, terdapat beberapa macam bentuk perlindungan hukum yang diberikan kepada Narapidana Anak. Hal tersebut akan dibahas secara detail di bawah ini.

\section{Agama}

Di dalam Lembaga Pemasyarakatan Anak Blitar saat ini hanya ada dua jenis agama yang dianut oleh narapidana anak yaitu Islam dan Kristen Protestan. Narapidana Anak yang memeluk Agama Islam berjumlah 128 (seratus dua puluh delapan ) orang. Serta yang menganut agama Kristen Protestan berjumlah 1 (satu) orang.

Dalam hal pemenuhan hak memeluk Agama di dalam Lembaga Pemasyarakatan Anak Blitar, secara keseluruhan sudah terpenuhi. Bagi yang beragama Islam terdapat masjid Al-Istiqomah yang berada di dalam area Lembaga Pemasyarakatan Anak Blitar. Selain adanya rumah ibadah yang berupa masjid, Narapidana Anak diwajibkan melaksanakan sholat dan mengaji.Pihak Lembaga Pemasyarakatan Anak Blitar juga melakukan kerjasama dengan Kementrian Agama dan Departemen Agama untuk memberikan ceramah kepada Narapidana Anak yang memeluk Agama Islam. Selain kegiatan keagamaan yang dilakukan oleh pihak Lembaga Pemasyarakatan Anak Blitar, ada kegiatan keagamaan yang dilakukan pada hari besar agama dengan bekerjasama dengan masyarakat dan organisasi swadaya masyarakat yang bernama Aisyiah kota Blitar. Dalam sektor agama, kendala yang dihadapi hampir sama pada anak - anak pada umumnya. Yaitu kurangnya kesadaran untuk melakukan ibadah sendiri.Oleh karena itu pihak Lembaga Pemasyarakatan Anak Blitar memberikan tugas kepada petugas yang ada untuk senantiasa memberikan contoh kepada Narapidana Anak dan supaya mengajak serta menegur Narapidana Anak yang sulit untuk melaksanakan 
ljtihad: Jurnal Wacana Hukum Islam dan Kemanusiaan, Volume 19, No. 1, Juni 2019: 125-145

ibadah.

Sarana dan prasarana lembaga pemasyarakatan anak Blitar

Untuk kelancaran dan ketertiban dalam rangka pelaksanaan pembinaan terhadap anak didik pemasyarakatan supaya tujuan dari pembinaan dapat tercapai diperlukan sarana fisik maupun non fisik. Pada Lembaga Pemasyarakatan Anak Blitar mempunyai 5 sel blok yaitu wisma bogenvil, wisma cempaka, wisma dahlia, wisma melati (perempuan) dan wisma anggrek yang semuanya dibagi lagi menjadi kamar-kamar yang keseluruhan berjumlah 36 kamar serta dapat menampung sampai 400 orang. Pada Lembaga Pemasyarakatan Anak Blitar terdapat sarana dan prasarana dalam rangka pelaksanaan pembinaan terhadap Anak Didik Pemasyarakatan yaitu : masjid, klinik kesehatan, perpustakaan, ruang kelas dan ruang keterampilan.

\section{Pegawai lembaga pemasyarakatan anak Blitar}

Walaupun tidak adanya seorang dokter yang menangani poliklinik yang ada di Lembaga Pemasyarakatan Anak Blitar, secara keseluruhan kesehatan Narapidana Anak telah tercukupi perlindungannya, nulai dari penanganan awal, asuransi kesehatan yang diselenggarakan oleh BPJS (Badan Penyelengaraan Jaminan Sosial) Kesehatan, sampai pada hal yang mengenai perawatan kesehatan rehabilitative sudah disediakan rujukan dari pihak Lembaga Pemasyarakatan Anak Blitar jika sewaktu-waktu Narapidana Anak perlu rujukan ke rumah sakit.

\section{Pendidikan}

Sektor pendidikan di dalam Lembaga Pemasyarakatan Anak Blitar secara keseluruhan telah terpenuhi. Bagi Narapidana Anak yang menempuh pendidikan Sekolah Dasar dan Sekolah Menengah Pertama ada kegiatan belajar mengajar setiap harinya. Hanya saja jam belajar di dalam lingkungan Lembaga Pemasyarakatan Anak Blitar mengikuti tenaga pengajar yang berasal dari Dinas Pendidikan, honor, dan tenaga pengajar sukarela. Baik Sekolah Dasar maupun Sekolah Menengah Pertama yang ada di dalam Lembaga Pemasyarakatan Anak Blitar adalah sekolah indukan dari luar lingkungan Lembaga Pemasyarakatan Anak Blitar, hal itu karena jika Narapidana Anak telah lulus menempuh tingkatan pendidikannya, ijazahnya dikeluarkan oleh Dinas Pendidikan. Oleh karena itu pihak Lembaga Pemasyarakatan Anak 
Blitar tidak mempunyai sekolah yang berdiri sendiri di bawah naungan Kemenkumham Devisi Pemasyarakatan. Bagi Narapidana Anak yang menempuh tingkatan Sekolah Menengah Atas atau sederajat, ditempuh melalui jalur kejar paket C, hal ini dikarenakan pihak Lembaga Pemasyarakatan Anak Blitar belum memiliki sekolah induk seperti yang ada pada tingkatan Sekolah Dasar dan Sekolah Menengah Pertama. Untuk kegiatan belajar mengajar disesuaikan dengan kurikulum yang diberlakukan oleh pemerintah.Narapidana Anak pada Lembaga Pemasyarakatan Anak Blitar dalam melaksanakan kegiatan belajar mengajar tidak diwajibkan untuk memakai seragam seperti pada anak yang menempuh pendidikan di luar lingkungan Lembaga Pemasyarakatan. Selain itu pula Narapidana Anak diberi kemudahan lainnya seperti buku yang telah disediakan oleh pihak Lembaga, dan tidak dipungut biaya apapun. Untuk data Narapidana Anak yang menempuh satuan pendidikan Sekolah Dasar berjumlah 11 (sebelas) orang dan Sekolah Menengah Pertama berjumlah 17 tujuh belas) orang.Sedangkan untuk kejar Paket $\mathrm{C}$ tidak ada, hal ini dikarenakan oleh tidak adanya Narapidana Anak yang lolos persyaratan administrasi.

Dengan adanya program pendidikan 9 (Sembilan) tahun, sangat membantu bagi Narapidana Anak yang sebelumnya telah putus sekolah.Sehingga pendidikan 9 (tahun) yang terjamin bagi Narapidana Anak sangat memberi manfaat untuk perkembangan intelektualnya demi masa depan yang lebih baik lagi dan diharapkan tidak melakukan tindak pidana dikemudian hari .selain itu juga Narapidana Anak mampu bersaing baik dalam persaingan usaha dan untuk mendapatkan pekerjaan dengan masyarakat pada umumnya, jika telah kembali ke lingkungan masyarakat luas.

Pada sektor Pendidikan ini, menurut penulis, secara keseluruhan telah memenuhi kebutuhan yang telah diamanahkan oleh Undang-undang Nomor 23 tahun 2002 tentang perlindungan anak dan perubahannya yaitu Undang-undang Nomor 35 tahun 2014 dan Undang-undang Nomor 17 tahun 2016 tentang perlindungan anak dan Peraturan Pemerintah Republik Indonesia Nomor 32 tahun 1999 tentang Syarat Dan Tata Cara Pelaksanaan Hak Warga Binaan Pemasyarakatan (Lampiran) yang mengatur hal-hal mengenai pendidikan Narapidana Anak di dalam Lembaga Pemasyarakatan tersebut. Selain hal itu Narapidana Anak juga telah dimudahkan dalam mengakses pendidikan dengan tidak adanya aturan untuk menggunakan seragam dan membeli buku pelajaran serta tidak 
dipungut biaya seperti sekolah formal pada umumnya.

Namun sangat disayangkan, Narapidana Anak yang menempuh satuan pendidik Sekolah Menengah Atas yang ditempuh melalui Kejar Paket C tidak ada yang lolos persyaratan administrasi padahal hal tersebut penting untuk meningkatkan intelektualitas (kecerdasan) Narapidana Anak agar pengetahuan dan kemampuan berpikir para Narapidana Anak yang nantinya diharapkan akan menunjang pelaksanaan program pembinaan yang lainya.

Dalam menanggulangi kendala yang ada pada sektor pendidikan pihak Lembaga Pemasyarakatan Kelas Blitar memberikan motivasi kepada Narapidana Anak yang kurang sadar pendidikan. Disini petugas lapas tidak pernah bosan untuk mengajak Narapidana Anak untuk melakukan kegiatan belajar mengajar. Dalam hal Narapidana Anak telah menempuh satuan pendidikan akan diberi kemudahan untuk melanjutkan satuan pendidikan yang selanjutnya. Selain itu ada pula wacana dari Kementrian Hukum dan Ham, untuk sektor pendidikan nantinya akan dilaksanakan dengan sistem pendidikan terbuka, dengan begitu Narapidana Anak nantinya akan menjalani kegiatan belajar mengajar tidak dilakukan setiap hari dengan harapan Narapidana Anak tidak merasa bosan dengan kegiatan belajar mengajar yang setiap hari dilaksanakan seperti pada hari ini. Selain itu juga pihak Lembaga Pemasyarakatan Anak Blitar juga dipermudah dalam penyelenggaraan pendidikan bagi Narapidana Anak dengan tidak mencari sekolah Indukan guna memenuhi hak pendidikan Narapidana Anak seperti yang ada selama ini.

\section{Kesehatan}

Hal ini guna menanggulangi kendala dalam hal sektor kesehatan. Perlu adanya suatu pemberian motivasi khusus bagi Narapidana Anak dalam menjaga kesehatannya sendiri. Disini para petugas senantiasa mengingatkan kepada Narapidana Anak untuk menjaga kebersihan lingkungan untuk menjaga kesehatan Narapidana Anak itu sendiri. Untuk itu ada jadwal kegiatan setiap harinya untuk menjaga kebersihan lingkungan, agar nantinya Narapidana Anak sadar akan kebersihan guna guna menjaga kesehatan mereka sendiri.

\section{Sosial}

Dengan adanya wali pemasyarakatan, fasilitas televisi dan alat-alat olahraga serta tersedianya buku, para Narapidana Anak dapat dengan leluasa untuk mengisi waktu luang yang ada 
dengan hal-hal positif. Tentunya ini sangat bermanfaat bagi Narapidana Anak untuk menyalurkan minat dan bakatnya dan nantinya dapat mengembangkan ilmu pengetahuannya melalui bahan bacaan yang tersedia.

Dari yang dijelaskan di atas, dapat diketahui bahwa pada dasarnya Narapidana Anak memiliki kesempatan bersosialisasi dan lain-lain yang berhubungan dengan sosialisasi Narapidana Anak yaitu berpartisipasi, menyatakan pendapat dan berfikir sesuai hati nurani dan agama, menerima informasi lisan atau tulisan sesuai dengan tahapan usia dan perkembangan anak, bebas

Kunjungan keluarga dan orang yang dikenal oleh Narapidana Anak dirasa sangat dibutuhkan selain untuk melepas rasa rindu dengan keluarga, Narapidana Anak juga mendapat pemberian dari pihak yang mengunjunginya selama pemberian tersebut bukan sesuatu yang dilarang.Pemberian tersebut biasanya berupa makanan, sehingga makanan tersebut tidak hanya dinikmati oleh Narapidana Anak yang bersangkutan, melainkan anak pidanya yang lainya bisa menikmatinya. Karena didalam pembinaan juga disertai tentang kebersamaan.

Menurut penulis mengenai kunjungan yang diterima oleh Narapidana Anak sudah bisa dikatakan baik. Hal ini dikarenakan yang dilakukan oleh pihak Lembaga Pemasyarakatan Anak Blitar telah disesuaikan dengan peraturan yang berlaku. Peraturan tersebut antara lain pada pasal 14 ayat (1) huruf h Undang-Undang Nomor 12 Tahun 1995 tentang pemasyarakatan merumuskan bahwa Narapidana Anak berhak menerima kunjungan keluarga, penasehat hukum, atau orang tertentu lainnya. Selain itu juga telah sesuai dengan pasal 30 Peraturan Pemerintah Republik Indonesia Nomor 32 Tahun 1999 Tentang Syarat Dan Tata Cara Pelaksanaan Hak Warga Binaan Pemasyarakatan (Lampiran). Selain itu pula masih ada kesempatan yang luas bagi keluarga Narapidana Anak yang berdomisili jauh atau yang memiliki kesibukan di hari kerja masih dapat melakukan kunjungan di hari libur.

\section{Pengurangan masa pidana (remisi)}

Untuk pengurangan masa pidana (remisi) terdapat syarat dan ketentuan yang telah dirumuskan dalam Pasal 34 ayat (2) daan (3) Peraturan Pemerintah Republik Indonesia Nomor 99 Tahun 2012 Tentang Perubahan Kedua Atas Peraturan Pemerintah Nomor 32 
Tahun 1999 Tentang Syarat Dan Tata Cara Pelaksanaan Hak Warga Binaan Pemasyarakatan. Syarat yang dimaksud adalah remisi sebagaimana dimaksud pada ayat (2) dapat diberikan kepada Narapidana dan Narapidana Anak yang telah memenuhi syarat berkelakuan baik, dan telah menjalani masa pidana lebih dari 6 (enam) bulan. Pada ayat (3) Persyaratan berkelakuan baik sebagaimana dimaksud pada ayat (2) huruf a dibuktikan dengan tidak sedang menjalani hukuman disiplin dalam kurun waktu 6 (enam) bulan terakhir, terhitung sebelum tanggal pemberian Remisi dan telah mengikuti program pembinaan yang diselenggarakan oleh LAPAS dengan predikat baik.

Pengurangan masa pidana (remisi) pasti diberikan jika Narapidana Anak telah memenuhi syarat-syarat yang telah ditetapkan. Jika membahas remisi, erat kaitannya dengan prilaku Narapidana Anak. Jika prilaku, Narapidana Anak melanggar aturan misalnya seperti berkelahi, menyelundupkan barang-barang yang dilarang (alat komunikasi, obat-obatan terlarang, senjata api maupun senjata tajam dan lain-lain), maka akan ada hukuman atas tindakan yang melanggar aturan tersebut, jika terkena hukuman, maka remisi tidak akan diberikan. Namun jika sudah terpenuhi akan berikan remisi karena hal tersebut adalah hak dari Narapidana Anak. Namun dengan adanya syarat-syarat tersebut, para Narapidana Anak secara tidak langsung diajarkan untuk berkelakuan baik, dan hal itu sangat membantu Narapidana Anak dalam merubah prilakunya supaya menjadi orang yang lebih baik dari sebelumnya.

Mengenai pemberian Remisi, ada banyak syarat yang tidak mudah bagi Narapidana Anak untuk memenuhinya. Untuk itu, Narapidana Anak berkewajiban untuk berkelakuan baik sehingga tidak menerima hukuman disiplin serta mendapat predikat baik dalam mengikuti program pembinaan yang ada jika ingin mendapatkan haknya atas remisi (pengurangan masa pidana). Jika dilihat dari salah satu syarat untuk mendapatkan remisi (pengurangan masa pidana) adalah berkelakuan baik, syarat ini juga menjadi bagian perlindungan Anak dari ancaman kekerasan. Hak itu dikarenakan kekerasan adalah salah dan bagi pelakunyaakan terkena hukuman disiplin.

\section{Kesempatan berasimilasi termasuk cuti menunjungi keluarga dan pembebasan bersyarat serta cuti menjelang bebas}

Kesempatan asimilasi hanya dapat diberikan jika Narapidana Anak memenuhi persyaratan yang dirumuskan dalam Pasal 36 ayat (2) huruf a Peraturan Pemerintah Republik Indonesia 
Nomor 99 Tahun 2012 Tentang Perubahan Kedua Atas Peraturan Pemerintah Nomor 32 Tahun 1999 Tentang Syarat Dan Tata Cara Pelaksanaan Hak Warga Binaan Pemasyarakatan, yaitu berkelakuan baik, aktif mengikuti program pembinaan dengan baik, dan telah menjalani $1 / 2$ (satu per dua) masa pidana. Selain itu juga ada pula syarat-syarat yang ditentukan dalam Peraturan Menteri Hukum Dan Hak Asasi Manusia Republik Indonesia Nomor M.2.Pk.04-10 Tahun 2007 .Dalam hal kendala pada pemberian pambebasan barsyarat.pihak Lembaga Pemasyarakatan Anak Blitar tidak dapat berbuat banyak jika mengenai penolakan dari masyarakat ataupun keluarga korban.Yang bisa dilakukan hanya berkoordinasi dengan penegak hukum yang berada di wilayah hukum tempat tinggal Narapidana Anak agar bisa melakukan pendekatan terhadap masyarakat dan keluarga korban supaya mau menaria Narapidana Anak yang mendapat pembebasan bersyarat.

\section{Pendekatan gender bagi perlakuan anak wanita}

Pendekatan gender dalam perlakuan anak bermaslah di LPKA Blitar dilakukan dengan tidak membedakan pria dan wanita. Namun demikian dalam proses assesmen awal ditemukan bahwa jumlah anak wanita yang usianya antara 12 sd 18 tahun sangat sedikit jumlahnya. Selama rentang waktu 10 tahun terakhir jumlah pelaku anak wanita hanya 2 orang. Sebenarnya proses perlakuan tidak jauh berbeda dengan anak pria, baik itu dalam hal pembinaan. Pola pendidikan sampai pada fasilitas yang diberikan.

\section{Model kurikulum LPKA Blitar}

Penerapan model kurikulum di LPKA Blitar dapat disebut sebagai Sistem Perlakuan Anak Didik Pemasyarakatan. Di bawah ini diuraikan model kurikulum yang dilaksanakan di LPKA Blitar.

Proses perjalanan anak didik lapas (Andikpas) adalah proses yang dilalui oleh anak didik dengan melalui standar yang berlaku yang dilakukan oleh setiap anak didik melalui tahapantahapan yang dilalui. Pertama, proses yang disebut input adalah awal dilalui andikpas dengan masa penahanan mulai $0-1 / 3$ MP yang disebut dengan tahap awal. Tahap awal ini dilalui dengan melakukan Administrasi Orientasi yaitu: (1) Masa pengamatan, pengenalan dan penelitian lingkungan; (2) Assesment (risiko, psikososial, ekonomi dan litmas); (3) Konseling Individual dan kelompok; (4) Pengenalan Hak dan Kewajiban Anak Didik (5) Perencanaan 
ljtihad: Jurnal Wacana Hukum Islam dan Kemanusiaan, Volume 19, No. 1, Juni 2019: 125-145

Program Pembinaan melalui sidang TPP (6) Pemantauan oleh Bapas dan Masyarakat; (7) Litmas Bapas, untuk program pembinaan tahap awal.

Kedua, dalam proses Administrasi Orientasi ini dilakukan juga pembinaan berupa: (1) Penetapan program pembinaan untuk Andikpas melalui sidang TPP (Tim Pengamat Pemasyarakatan); (2) Pemantauan oleh Bapas (3) Evaluasi. Ketiga, tahap berikutnya disebut dengan Tahapan Lanjutan untuk masa penahanan kedua dengan durasi waktu 1/3 sd 1/2 MP dengan perlakuan pada anak didik lapas berupa: (1) Assesment; (2) Melanjutkan dan meningkatkan program pembinaan tahap awal; (3) Mengandung partisipasi masyarakat dan keluarga untuk kegiatan bersama di Lapas; (4) Konseling; (5) Pemantauan oleh Bapas dan (6) Evaluasi. Selanjutnya dalam tahapan lanjutran ini juga dilakukan penerusan masa penahanan dengan durasi waktu 1/2-2/3 MP ASIMILASI dengan perlakuan sebagai berikut: (1) Assesment; (2) Sekolah luar Lapas; (3) Cuti mengunjungi Keluarga (CMK); (4) Olahraga; (5) Menjalankan Ibadah; (6) Konseling; (7) Pemantauan Oleh Bapas; dan (8) Evaluasi.

Dari uraian diatas dapat dikaji bahwa posisi Andikpas untuk mentut ilmu secara formal diposisikan pada istilah sekolah luar lapas. Istilah ini sesungguhnya merujuk pada proses pendidikan yang dalam prakteknya mendatangkan guru ke dalam lapas dengan adanya MoU dengan Dinas pendidikan untuk tingkat SD/SMP.

Keempat, tahap selanjutnya adalah TAHAP AKHIR 2/3 MP-BEBAS dengan perlakuan sebagai berikut: (1) Assesment; (2) Pelaksanaan Program Reintegrasi Andikpas antara lain: (Pembebasan Bersyarat dan Cuti Menjelang Bebas). Tahap ini adalah tahap akhir sebagai output yang memenuhi tujuan pemasyarakatan yaitu Reintegrasi Sosial: Hidup, Kehidupan dan Penghidupan.

Penerapan kurikulum dalam LPA Blitar di dalam sistem di atas disebut dengan sekolah luar lapas, yang istilah ini sesungguhnya dalam praktek sekolah dalam Lapas, dimana guru diundang dan datang untuk mengajar di Lapas. Kurikulum menjadi bagian penting dalam penyelenggaraan pembinaan narapidana anak di LPA Blitar. Kurikulum akan menentukan arah dan keberhasilan program pembinaan. Hasil wawancara dengan bagian yang terkait dengan kurikulum di LPA Blitar menyatakan:

"Kurikulum pembinaan narapidana anak mengacu pada pedoman perlakuan anak di LPA. Pembinaan narapidana anak bertujuan untuk membangkitkan motivasi atau dorongan 
pada diri anak ke arah pencapaian tujuan pembinaan, memberi kesempatan bagi anak untuk meningkatkan pendidikan dan ketrampilan guna mempersiapkan diri hidup mandiri di tengah masyarakat setelah bebas menjalani pidana, dan mendorong masyarakat untuk berperan secara aktif dalam penyelenggaraan pemasyarakatan"

Dari paparan data tersebut dapat diambil kesimpulan bahwa kurikulum merupakan kerangka dasar materi yang akan dibahas dalam pembinaan narapidana anak, oleh sebab itu dalam penyusunannya di LPA Blitar disusun dengan mempertimbangkan visi, misi, dan tujuan LPA. Kurikulum dibuat sedemikian rupa disesuaikan dengan kebutuhan belajar peserta didik (binaan) dan tujuan pembinaan, sehingga diharapkan dapat meningkatkan pengetahuan, keterampilan, dan sikap anak didik (binaan) di LPA Blitar.

Selain hal tersebut, kurikulum yang disusun juga bertujuan agar anak didik (binaan) mampu mengubah perilakunya yang tidak baik/ melanggar norma, baik norma susila, masyarakat, maupun norma hukum sehingga kembali taat terhadap norma yang ada dalam masyarakat dengan penuh kesadaran, tidak lagi mengulangi kesalahannya. Dengan demikian anak didik (binaan) mampu hidup bermasyarakat dengan baik dan memiliki bekal keterampilan yang dapat digunakan dan dikembangkan di masyarakat.

Proses penentuan kurikulum berdasarkan sidang tim perumus yang didalamnya melibatkan para pelatih, kepala seksi kegiatan kerja, kepala sub seksi pembinaan, dan wali anak didik. Kurikulum yang telah disusun dan dibakukan selanjutnya oleh pengelola program pendidikan dilakukan langkah-langkah pelaksanaannya dengan menyusun Garis-Garis Besar Program Pembelajaran (GBPP) bersumber dari kurikulum yang telah dibuat, meliputi penentuan siapa gurunya, pesertanya, metode pembelajarannya, media pembelajarannya, waktu, dan tempat pelaksanaannya.

Dalam pelaksanaan kurikulum yang melaksanakan dan menggunakan kurikulum adalah guru dan peserta didik. Berikut pernyataan tentang pelaksanaan kurikulum, kepala bagian pembinaan anak menyatakan:

"Dalam kegiatan pembelajaran untuk pembinaan narapidana anak dilakukan sepenuhnya di dalam lokasi LPA, guru didatangkan dari sekolah yang telah menjalin kerjasama dengan LPA Blitar. Proses pembelajaran sepenuhnya hampir sama dengan pembelajaran di sekolah pada umumnya, baik pada anak didik yang setingkat dengan jenjang pendidikan dasar (SD) 
maupun menengah (SMP). Kurikulum yang digunakan dalam pendidikan narapidana anak di LPA Blitar ini menggunakan model KTSP.”

Pada bagian yang lain juga dinyatakan sebagai berikut:

"Pendidik yang datang ke LPA, adalah juga guru resmi di SD, sehingga dalam pelaksanaan pembelajarannya standar yang digunakan sama dengan yang digunakan di sekolah formal, hanya saja tempat pembelajarannya saja yang yang berbeda, status anak didiknya yang berbeda, sehingga beberapa penyesuaian biasanya secara otomatis naluri pendidik (guru) dapat menyesuaikan dengan kondisi lingkungan belajar. Penyusunan persiapan pembelajaran (Silabus dan RPP) sampai dengan evaluasinya juga sesuai dengan standar pendidikan di sekolah formal, bahkan untuk evaluasi belajarnya pun sesuai dengan standar ujian nasional seperti UN."

Dari pernyataan tersebut di atas dapat disimpulkan bahwa pendidik (guru) dalam kegiatan pembelajaran melakukan strategi yang disesuaikan dengan karakteristik peserta didik dan lingkungan belajarnya, tanpa megurangi muatan standar kompetensi yang ditetapkan secara nasional dalam kurikulum pendidikan formal. Dengan demikian kegiatan evaluasi pembelajarannya juga mengikuti standar nasional namun dengan teknis pelaksanaan yang disesuaikan.

\section{Penutup}

Pendekatan kriminologi yang dilakukan dalam memberikan muatan materi kurikulum terhadap pembentukan model kurikulum pembinaan narapidana anak di lembaga pemasyarakatan anak adalah pendekatan Agama, Sarana dan prasarana Lembaga Pemasyarakatan Anak Blitar, Optimalisasi peranan Pegawai Lembaga Pemasyarakatan Anak Blitar, Penerapan Pendidikan formal dalam Lapas, Pemeliharaan dan Perawatan Kesehatan, Daya dukung terciptanya Pemulihan Sosial, Pengurangan Masa Pidana (remisi), Kesempatan berasimilasi termasuk cuti menunjungi keluarga dan pembebasan bersyarat serta cuti menjelang bebas. Sedangkan pendekatan gender dalam perlakuan anak bermaslah di LPKA Blitar dilakukan dengan tidak membedakan pria dan wanita. Namun demikian dalam proses assesmen awal ditemukan bahwa jumlah anak wanita yang usianya antara 12 sd 18 tahun sangat sedikit. Selama rentang waktu 10 tahun terakhir jumlah pelaku anak 
Pendekatan kriminologi dan gender terhadap model kurikulum... (Saifullah, dkk.)

wanita hanya 2 orang. Sebenarnya proses perlakuan tidak jauh berbeda dengan anak pria, baik itu dalam hal pembinaan pola pendidikan sampai pada fasilitas yang diberikan.

Hasil akhir pembentukan model kurikulum pembinaan narapidana anak di lembaga pemasyarakatan anak (LPKA) Blitar dapat disebut sebagai Sistem Perlakuan Anak Didik Pemasyarakatan. Sistem ini terdiri atas Input berupa tahap awal 0 s/d 1/3 MP dengan pola admini orientasi ; tahap lanjutan terdiri $1 / 3$ sd $1 / 2$ MP dan $1 / 2$ sd $2 / 3$ MP ; tahap akhir 2/3 MP-Bebas yang diakhir dengan tercapainya tujuan pemasyarakatan yaitu Reintegrasi Sosial: hidup, kehidupan dan penghidupan.

\section{Daftar Pustaka}

Abdulsyani, Sosiologi Kriminalitas, Remadja Karya, Bandung, 1987.

Arif, Barda Nawawi, Beberapa Aspek Kebijaksanan Penegakan dan Pengembangan Hukum Pidana, Bandung: Citra Aitya Bakti, 1998.

Arif, Barda Nawawi, Penetapan Pidana Penjara dalam Perundang-undangan dalam rangka Usaha Penanggulangan Kejahatan, Disertasi, UNPAD, Bandung, 1986.

_.,'Ruang Lingkup Penegakan Hukum Pidana dalam Konteks Politik Kriminal”, makalah seminar, UNDIP, Semarang, 1990.

_Upaya Non-Penal dalam Kebijakan Penang-gulangan Kejahatan, makalah pada Seminar Kriminologi, Semarang, 1991.

, Beberapa Pokok Pikiran Dalam Aturan Umum Konsep KUHP Baru, makalah pada Seminardi IAIN Sunan Kalijaga, Yogyakarta, 1993 a.

, Kebijakan Kriminalisasi dan Dekriminalisasi dalam RUU KUHP (Sumber, Pola dan Sistem Kebijakan Kriminalisasi dan Dekriminalisasi), makalah Seminar di UII, 15 Juli 1993 b.

,"Beberapa Aspek Baru Dalam KUHP Baru” Bahan Penataran Nasional Hukum Pidana dan Kriminologi, Semarang, 1993 c.

—, Bunga Rampai Kebijakan Hukum Pidana, Citra Aditya Bakti, Bandung, 1996. , Batas-batas Kemampuan Hukum Pidana dalam Penanggulangan Kejahatan, Makalah pada Seminar Nasional "Pendekatan Nonpenal dalam Penanggulangan Kejahatan”, FH UNDIP, Semarang, 2 September 1996.

, Beberapa Aspek Kebijakan Penegakan dan Pengembangan Hukum Pidana, DIP Undip Thn 1997-1998. 
ljtihad: Jurnal Wacana Hukum Islam dan Kemanusiaan, Volume 19, No. 1, Juni 2019: 125-145

Masalah Penegakan Hukum dan Kebijakan Penanggulangan Kejahatan, Citra Aditya Bakti, Bandung, 2001.

Kapita Selekta Hukum Pidana, Program Magister Ilmu Hukum, Nopember 2002.

Brannen, Julia Memadu Metode Penelitian, Alih bahasa H.Nuktah, Pustaka Pelajar,Yogyakarta, 1997.

Cik Hasan Bisri dalam Pilar-pilar Penelitian Hukum Islam dan Pranata Sosial, Raja Grafindo, Jakarta, 2004.

Faisal, Sanapiah Penelitian Kualitatif, Dasar-dasar dan Aplikasi, YA3, Malang, 1990.

Hilary M. Lips, Sex \& Gender an Introduction, California, London, Toronto: Mayfield Publishing Company, 1993.

Heofnagels, G.Peter, The Other Side of Criminology, Holland : Kluwer Deventer, 1973.

Johnny Ibrahim, Teori dan Metodologi Penelitian Hukum Normatif, Malang: Bayumedia Publishing, 2010.

Kartini Kartono, Gangguan-Gangguan Psikis, Bandung: Sinar Baru, 1981.

Linda L. Lindsey, Gender Roles a Sociological Perspective, $m$ New Jersey: Prentice Hall, 1990.

Made Sadhi Astuti, Hukum Pidana Anak Dan Perlindungan Anak, Malang: UM Press, 2003.

Marzuki, Peter Mahmud, Penelitian Hukum, Jakarta: Kencana, 2005.

Miles, Matthew B. and A. Michael Huberman, Qualitative Data Analysis,. A Sourcebook of: New Methods, Sage Publications, 1984.

Moleong, Lexy. J Metodologi Penelitian Kualitatif, Remaja Rosdakarya, Bandung, 1995.

Muhadjir, Noeng Metode Penelitian Kualitatif, Rake Sarasin, Yogyakarta, 1992.

Muladi dan Barda Nawawi Arief, Teori-teori dan Kebijakan Pidana, Alumni, Bandung, 1982.

,Ruang Lingkup Penegakan Hukum Pidana dalam Konteks Politik Kriminal, makalah dalam Seminar Kriminologi Konservasi: Sumbangan Disiplin Non Hukum dalam Penegakan Hukum Pidana. Lembaga Kriminologi Fak. Hukum UNDIP, Semarang, 11-13 Nopember 1986. ,Bunga Rampai Hukum Pidana, Alumni, Bandung, 1992.

Muladi, HAM, Politik dan Sistem Peradilan Pidana, Gajah Mada, University Press, Yogyakarta, 1983.

Kapita Selekta Sistem Peradilan Pidana, BP UNDIP, Semarang, 1995.

Nasution, S.Metode Penelitian Naturalistik Kualitatif, Tarsito, Bandung, 1996. 
Pendekatan kriminologi dan gender terhadap model kurikulum... (Saifullah, dkk.)

Nawawi, Hadari, Metode Penelitian Bidang Sosial, Gajah Mada, University Press, Yogyakarta, 1983.

Patton, Michael Quinn, Qualitative Evaluation Methods, Printing, London, Sage Publication, 1989.

Reckless, Walter. C, The Crime Problem, Third Edition, New York: Appleton-Century-Graft, Inc, 1961.

Reksodiputro, Mardjono, Pembaharuan Hukum Pidana, Lembaga Kriminologi, UI, Pers Jakarta, 1995.

Silverman, David, Interpreting Qualitative Data. Methods for Analysing Talk, Text and Interaction, Sage Publication, London, 1993.

Strauss, Anselm \& Juliet Corbin, Basic of Qualitative Research: Grounded Theory and Techniques, California : Sage Pub.Inc, 1990.

Sumadi, Metodologi Penelitian, Rajawali Perspektif, Jakarta, 1991.

Soedjono, dkk., Metode Penelitian, Suatu Pemikiran dan Penerapan, Rineka Cipta, Jakarta, 1999.

Soejono, Abdurrahman. Metode Penelitian Hukum. Rineka Cipta: Jakarta. 2003.

Soekanto, Soerjono. Mamudji, Sri. Penelitian Hukum Normatif: Suatu Tinjauan Singkat. Raja Grafindo Persada : Jakarta. 2003.

Soerjono Soekanto dan Sri Mamudji, Penelitian Hukum Normatif, Jakarta: Rajawali Pers, 1985.

Soemitro, Rony Hanitijo Metodologi Penelitian Hukum dan Jurimetri, Ghalia Indonesia, Jakarta, 1990.

Showalter Elaine (Ed.), Speaking of Gender, (New York \& London: Routledge, 1989

Wilson, H.T. Sex and Gender, Making Cultural Sense of Civilization. Leiden, New York, Kobenhavn, Koln: EJ. Brill, 1989.

\section{Kamus dan Ensiklopedia:}

John M. Echols dan Hassan Shadily, Kamus Inggeris Indonesia (Cet. I; Jakarta: Gramedia, cet. XII, 1983)

Victoria Neufeldt (ed.), Webster's New World Dictionary (New York: Webster's New World Cleveland,1984).

Helen Tierney (Ed.), Women's Studies Encyclopedia Vol. I (NewYork: Green Wood Press). 
